\title{
IASPEI: its origins and the promotion of global seismology
}

\author{
Johannes Schweitzer ${ }^{1,3}$ and Thorne Lay ${ }^{2}$ \\ ${ }^{1}$ NORSAR, P.O. Box 53, 2007 Kjeller, Norway \\ ${ }^{2}$ University of California Santa Cruz, Department of Earth and Planetary Sciences, Santa Cruz, CA 95064, USA \\ ${ }^{3}$ CEED, University of Oslo, P.O. Box 1028, Blindern, 0315 Oslo, Norway \\ Correspondence: Johannes Schweitzer (iaspei@norsar.no)
}

Received: 15 October 2018 - Revised: 31 December 2018 - Accepted: 3 January 2019 - Published: 16 April 2019

\begin{abstract}
International cooperation in seismology emerged rapidly at the beginning of the 20th century following the successful recording of earthquakes at great distances. The International Seismological Association (ISA) founded in 1904 was dissolved in 1922 and evolved into the Seismology Section of the International Union of Geodesy and Geophysics (IUGG), ultimately becoming the International Association of Seismology and Physics of the Earth's Interior (IASPEI) to recognize the important role of the structure and physical properties of the Earth. Through the last hundred years, the commissions and working groups of the association have played a major role in setting international standards in such areas as the naming of seismic phases, data exchanges, travel-time tables, magnitude scales, and reference Earth models. The activities of IASPEI continue to have a focus on the societal impacts of earthquakes and tsunamis, with four regional commissions playing a major role in promoting high standards of seismological education, outreach, and international scientific cooperation.
\end{abstract}

\section{Introduction}

The International Association of Seismology and Physics of the Earth's Interior (IASPEI) has origins in the last decades of the 19th Century, when seismology was emerging as an important discipline within the newly established scientific field of geophysics. At that time seismology rapidly evolved from a predominantly phenomenological topic to a more theory-based science with expanding instrumental observations validating predictions from elasticity. During this period, scientists in many countries began to systematically collect data for macroseismically observed earthquakes, with approximate locations of these events being only known on the basis of such data. In some countries, scientists and/or their governments established special committees or commissions to do such work. To the best of our knowledge, the Erdbebenkommission der Schweizerisch Naturforschenden Gesellschaft (Earthquake Commission of the Swiss Society for Natural Scientists) was the first such commission, founded in Switzerland in 1878, followed in 1879 by the Regio Uffizio Centrale di Meteorologia e Geodinamica (Royal Central Office for Meteorology and Geodynamics) in Italy.
In Japan, the first nationwide working service for earthquake observations was established after the foundation of the initial worldwide Seismological Society in 1880 . During the following years, earthquake commissions, committees or equivalent institutions were founded in many European countries (see, for example, Sieberg, 1904). In parallel, new types of seismological instruments were developed and installed in Italy, Japan, and Germany, and a more or less continuous registration of sparse global ground motions became possible from the 1880 s on. Detailed descriptions of the history of development of ground motion recording instrumentation in the early days of seismology can be found in Ehlert (1898), Berlage Jr. (1930), Dewey and Byerly (1969), and Ferrari (1990, 1992).

Because of improved instrumentation after the late 1890s, seismic observations were increasingly published with physically measured parameters, i.e., measured onset times, dominant periods, and amplitudes of seismic waves. However, seismologists were still learning how to interpret their observations, mostly empirically. By the early 1900s, first-order features of the seismic records were being understood as the 
recording instruments produced seismograms with enough resolution in time and dynamic range to distinguish between onsets of all three theoretically expected wave types (i.e., longitudinal or primary waves ( $\mathrm{P}$ waves) and shear or secondary waves ( $\mathrm{S}$ waves) traveling through the interior of the Earth as body waves, as well as surface or long period waves ( $\mathrm{L}$ waves) traveling along the Earth's surface). The first versions of the current nomenclature for seismic phases were developed (von dem Borne, 1904; Bormann et al., 2013). Then, phase-specific observations began to be collected and published in seismic bulletins. A detailed description of the different types of seismic bulletins and their development until 1920 can be found in Schweitzer and Lee (2003).

One key discovery of the early days of seismology was the first observation of a teleseismic signal from an earthquake at about $80^{\circ}$ epicentral distance by Ernst von Rebeur-Paschwitz (1861-1895, Fig. 1). This astronomer had installed two identical horizontal pendula at Potsdam and Wilhelmshaven in Germany, separated by a distance of about $240 \mathrm{~km}$. His intent was to measure ground movements caused by the gravitational effect of celestial bodies (Moon, Sun, comets, etc.), which he achieved: Rebeur-Paschwitz confirmed for the first time the theoretically expected movements of the solid Earth due to the tides (von Rebeur-Paschwitz, 1892). On 17 April 1889, he recorded strong signals with both instruments (Fig. 2) and worked to exclude all types of astronomical and non-celestial explanations. In a letter published in Nature, he associated his observations with a large earthquake felt on the Izu Peninsula (Izu Hantō), Japan, and located west of Izu Ōshima $\left(34.75^{\circ} \mathrm{N}, 139.33^{\circ} \mathrm{E}\right)$ by the Central Meteorological Observatory in Tokyo (von RebeurPaschwitz, 1889). More about von Rebeur-Paschwitz and his contributions to seismology can be found in Davison (1978) or Schweitzer (2003). With this observation, seismology changed from a local/regional focus to a global science. Von Rebeur-Paschwitz continued to search for teleseismic signals, perceiving the advantages of using seismic waves as a tool to investigate the Earth's interior, and came in contact with the British seismologists working at that time in Japan. In his last publication (von Rebeur-Paschwitz, 1895) he argued for establishing a global network of seismometer stations with globally synchronized timing (Greenwich Mean Time) and an internationally centralized bureau to collect global seismological observations.

\section{1904-1922: the International Seismological Association (ISA) as IASPEI ancestor}

Georg C. K. Gerland (1833-1919) presented von RebeurPaschwitz's proposal at the Sixth International Geographical Congress, London, in 1895 and promoted it further after von Rebeur-Paschwitz's early death. The ideas were embraced by many colleagues and in 1901 Gerland welcomed colleagues from Austria-Hungary, Belgium, Denmark, Ger-

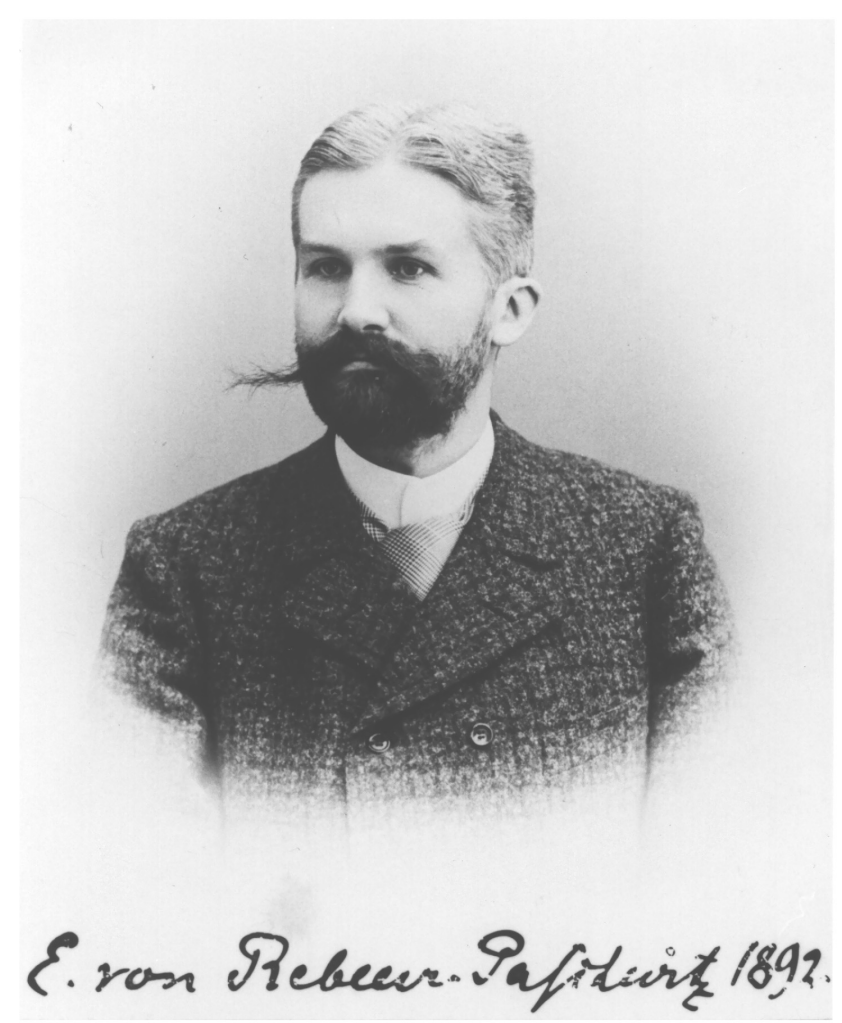

Figure 1. Ernst von Rebeur-Paschwitz (1861-1895). Courtesy of Universitätsarchiv Tübingen (UAT 209/108, B1 10).

many, Italy, Japan, Russia, and Switzerland at the First International Seismological Conference in Strasbourg, at that time a town in Germany, to discuss seismology and how to organize international seismological cooperation. In addition, colleagues from France, Great Britain, Greece, New Zealand, Norway, Portugal (Azores), Sweden, and the Netherlands sent their greetings and excuses for not being able to participate in the conference (see Rudolph, 1902). The not always politically easy discussions (e.g., dichotomy between a governmental and scientific association) were continued during the Second International Seismological Conference in 1903 (also in Strasbourg) with delegates and participants from 20 states, and this resulted in the drafted convention for an international organization for which states could become paying members; the International Seismological Association (ISA) (see Rudolph, 1904). The ISA convention entered into force on 1 April 1904 with 18 states as founding members and was planned to continue for a period of 12 years (until 31 March 1916). More details about the discussions and politics involved in the ISA foundation can be found in Rudolph (1902, 1904), Hodgson (1967), Rothé (1981), and Schweitzer (2003, 2007). As proposed by von Rebeur-Paschwitz, an important part of ISA became the newly founded Central Bureau located with its Director in Strasbourg. Years later, in 1927, Davison dedicated his monograph The Founders of Seismology to von Rebeur- 

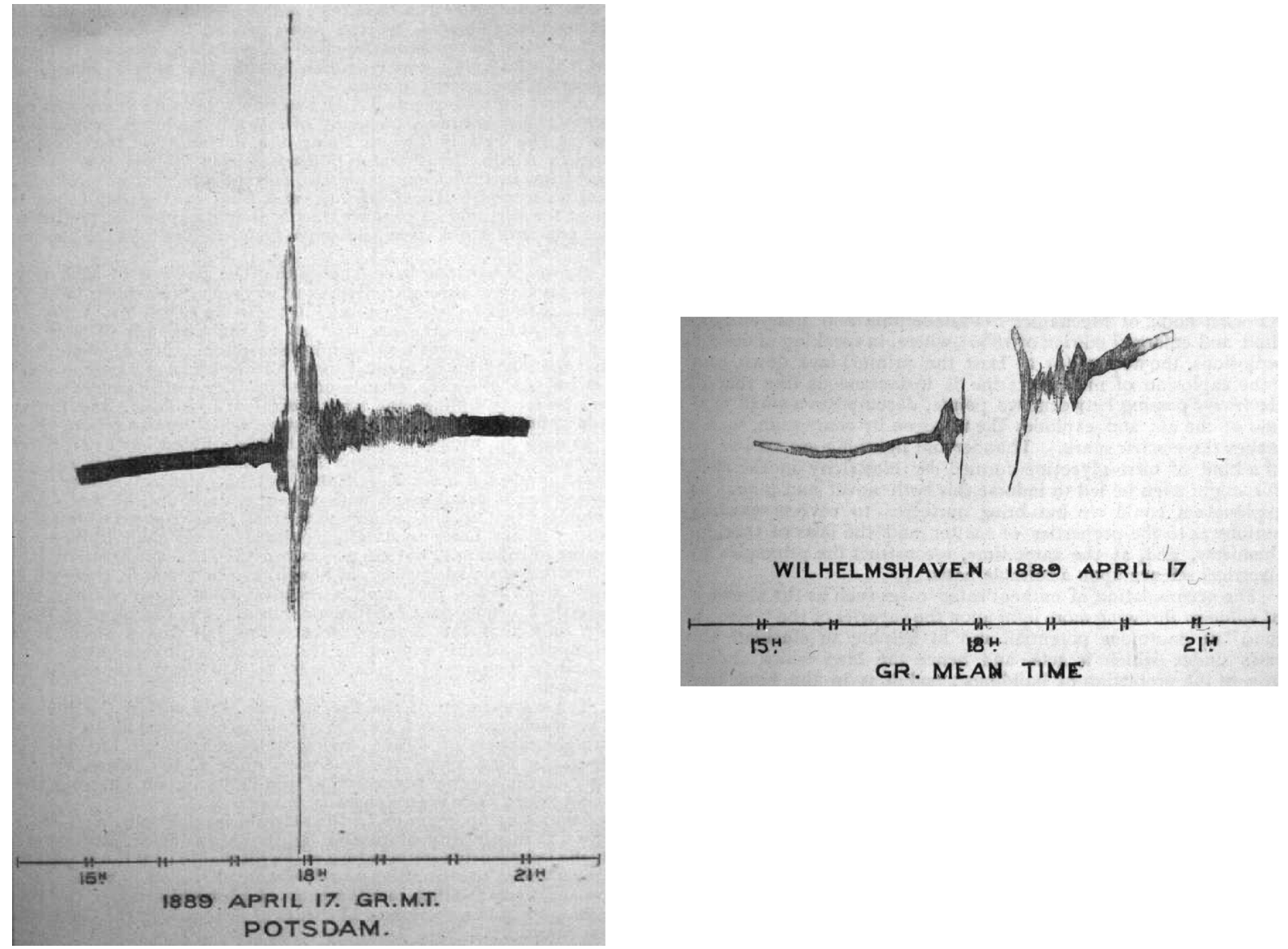

Figure 2. The 17 April 1889 seismogram records in Potsdam and Wilhelmshaven, from von Rebeur-Paschwitz (1889).

Paschwitz along with John Milne (1850-1913) and Fusakichi Omori (1868-1923). Following Rothé (1981), Gerland can be called the founder of IASPEI, but the fundamental ideas stem from von Rebeur-Paschwitz.

The main tasks of the Central Bureau were the collection of observed parametric data from all globally distributed seismic stations, associating these observations to seismic events, locating these events, and publishing a global bulletin. During the following years, the Central Bureau

- published global and regional earthquake catalogues and bulletins for macroseismically and instrumentally observed earthquakes for the years 1903-1908 (for details see Schweitzer and Lee, 2003);

- published monographs and articles about different aspects of seismology, as macroseismic studies, instrumentation, event location techniques, and special publications on important earthquakes;

- distributed newsletters (Mitteilungen des Zentralbureaus der Internationalen Seismologischen Assoziation) during World War I with similar contents;
- installed and supported two international seismic stations, one on Iceland and one in Lebanon;

- edited the globally distributed German issue of Prince Boris Galitzin's classical textbook Vorlesungen über Seismometrie (Galitzin, 1914);

- and organized an evaluation competition on seismographs.

An ISA publication list can be found in the archive section of the IASPEI website (http://iaspei.org/documents/ publications, last access: 22 January 2019).

A permanent commission was formed as a steering committee with an ISA President and a Secretary General during the Berlin conference (1905), and it met again in Rome (1906), The Hague (1907), Zermatt (1910), Manchester (1911), and Strasbourg (1922). General assemblies of ISA were held jointly with the meetings of the permanent commission in The Hague (Fig. 3), Manchester, and Strasbourg. The ISA convention had expired during World War I in 1916 and was not extended. Many seismic stations worldwide stopped operating (Schweitzer and Lee, 2003) because the staff had to participate in the war, and the international 
cooperation in seismology largely broke down. After World War I, international scientific cooperation was reorganized in a framework devised by the winning powers, with the International Union of Geodesy and Geophysics (IUGG) being founded in 1919, at the General Assembly of the International Research Council. In April 1922, the International Seismological Association was officially dissolved by the Strasbourg General Assembly (de Kövesligethy, 1922; Rothé, 1981). From this meeting, the delegates directly traveled to the First IUGG General Assembly in Rome, in May 1922, where the Seismology Section was formed as part of the IUGG.

\section{1922: the International Association of Seismology} and Physics of the Earth's Interior (IASPEI) as part of IUGG

The Seismology Section of the IUGG continued working in the spirit of ISA and changed its name to the International Association of Seismology at the Fourth IUGG General Assembly, in Stockholm, in 1930. Later, during the Ninth IUGG General Assembly in Brussels, in 1951, the association again changed its name to the International Association of Seismology and Physics of the Earth's Interior (IASPEI). For detailed accounts of the organizational history of IASPEI, see Hodgson (1967), Rothé (1981), and Adams (2002).

For about 50 years, the official Bureau of the Association was located in the now French town of Strasbourg, as the Central Bureau of ISA had been before, where the Secretaries General Edmond Rothé (1873-1942) and his son JeanPierre Rothé (1906-1991) edited and published the Publications du Bureau Central Séismologique International as Série A, Travaux Scientifiques (1924-1968), and as Série B, Monographies (1924-1937), as well as the Proceedings and Reports from the assemblies (Comptes Rendus). In addition, the Bureau in Strasbourg also continued to publish preliminary seismic bulletins and earthquake locations. However, in 1922, the compilation of the final global seismic bulletin was ceded by the association to Herbert H. Turner (18611930) in Oxford, who had already published the Bulletin of the British Association of the Advancement of Science, Seismology Committee for the years 1913-1917, which was a continuation of John Milne's Shide Circulars (1899-1912) (for more details see Schweitzer and Lee, 2003). The IASPEI bulletin for the years 1918-1963 was edited and published as the International Seismological Summary (ISS) in the UK (Stoneley, 1970). However, during and after World War II, a period of decline for international cooperation in seismology occurred (as during and after World War I): again, many seismic stations had to interrupt their operation and seismic monitoring became quite fragmentary.

As successor to the ISS, the International Seismological Centre (ISC) was set up with the help of UNESCO in 1964 to produce the global Bulletin of the International Seismologi- cal Centre. The ISC is no longer a formal part of IASPEI, but it operates under the umbrella of IASPEI and has always sustained very close scientific links with IASPEI, as demonstrated by the ISC Governing Council having its meetings during the biannual IASPEI assemblies. Summaries of the ISC activities can be found in the yearly reports of the ISC Director (http://www.isc.ac.uk/docs/dirreport/, last access: 22 January 2019).

\section{Some scientific achievements by IASPEI during the last 100 years}

After recognizing the need for international cooperation in seismology, many scientific achievements have been connected with IASPEI and its forerunners. Of course, most scientific discoveries are related to individual scientists, but the association provided seismologists and geophysicists a forum to meet regularly and exchange ideas, and to present and discuss their findings. However, some of these achievements are directly connected with the work within the association or were later adopted by the association and became thereby international standards.

During the last nine decades, the association had different commissions and working groups which played an unsurpassed role in unifying seismological observations; e.g., naming seismic phases, defining measurement procedures, testing seismic instruments, defining standard formats for data exchange, collecting and distributing seismological software, improving the network of seismic stations, producing reference Earth models, and publishing scientific results.

During the first decades of the last century, the principal layered structure of the Earth with a crust, mantle, and core had been revealed by different seismologists. However, Turner's discovery of seismic events with hypocenters located deep in the upper mantle was only possible with the help of globally distributed seismic stations and the collection of seismic observations by the ISS and can be counted as a direct result of association activities. Over subsequent decades, several contributions during association assemblies and in their publications by different authors were related to the problem of understanding deep focus events.

The data collection of the association during the late 1920s and early 1930s provided a source for Inge Lehmann's (1888-1993) early travel-time table studies. The highlight of these studies, partly supported by a grant of the association, was the publication of an article in the Travaux Scientifiques with one of the shortest titles ever: $P^{\prime}$. In this paper, Inge Lehmann proposed the existence of an inner core of the Earth (Lehmann, 1936). In the same year, during the Sixth IUGG General Assembly in Edinburgh, Inge Lehmann became the first female member of the IASPEI Executive Committee.

In general, seismic travel-time tables and seismic-phase identification have long been a major topic of interest for IASPEI. IASPEI published several travel-time tables for dif- 


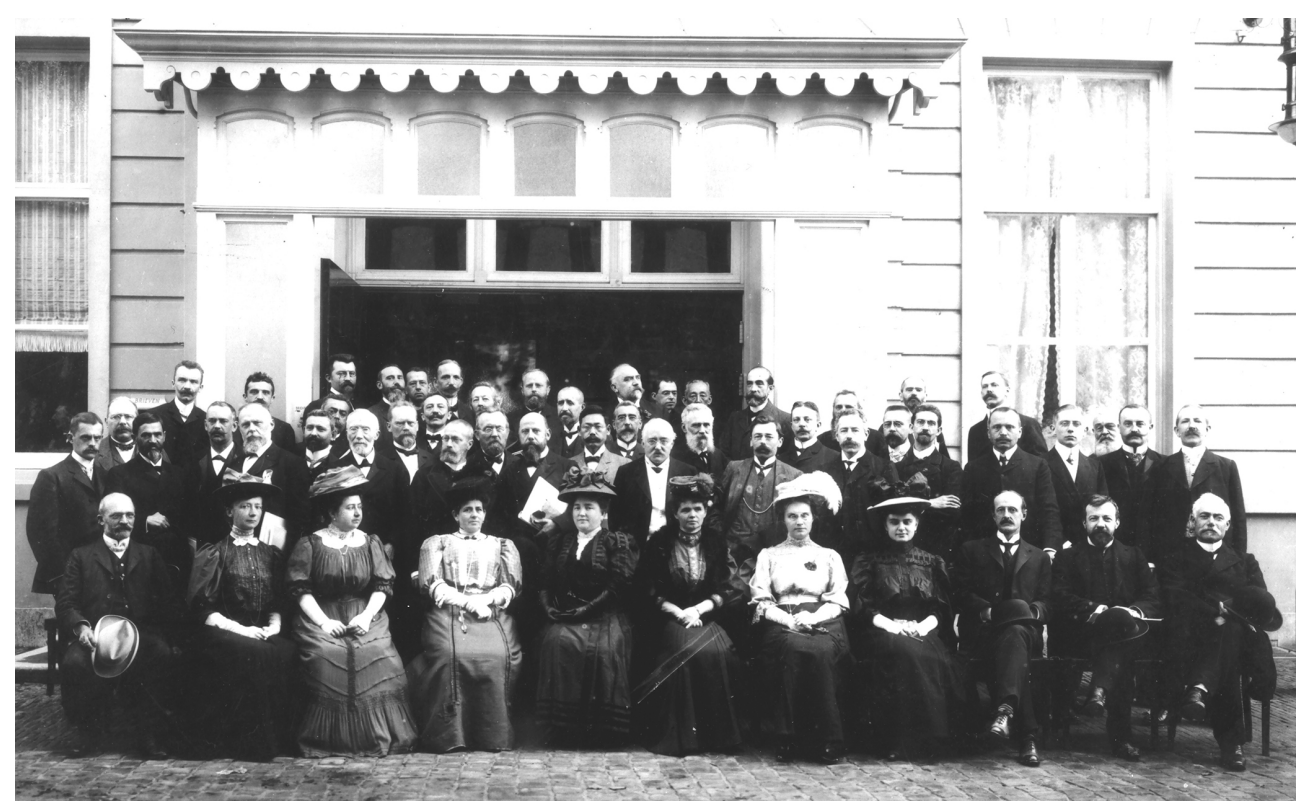

Figure 3. Participants of the First General Assembly of the International Seismological Association in The Hague, the Netherlands, 21-25 September 1907. Courtesy of the German GeoForschungsZentrum (GFZ, German Research Centre for Geosciences), Potsdam.

ferent seismic phases from different authors and founded, during the Fifth IUGG General Assembly in Lisbon (1933), a commission for the publication of new seismic travel-time tables. Mostly derived from the data collection at the ISS, the result of this international effort was the Jeffreys-Bullen tables published in its final version in 1940 (Jeffreys and Bullen, 1940). These seismic travel-time tables became the primary basis for seismic event locations worldwide and were used at the ISS/ISC until 2008.

The relationship between ISS/ISC and IASPEI can be described as symbiotic. Based on the data collections in the seismic bulletins, scientists investigated the internal structure of the Earth and ISS/ISC staff were and are active in the IASPEI Commission of Seismological Observation and Interpretation and in promoting the standardization of routine analysis at the seismological observatories to produce better seismic bulletins such as the International Seismic Bulletin Format (ISF), The IASPEI Standard Seismic Phase List, and The new IASPEI standards for determining magnitudes from digital data and their relation to classical magnitudes, which are all part of the IASPEI New Manual of the Seismological Observatory Practice (NMSOP-2) (Bormann, 2012). This manual is the latest issue of a series of IASPEI-supported publications, which started in the 1950s as a tool to improve and standardize seismological analysis practice and knowledge worldwide.

Without this cooperation, the great achievements in understanding the dynamics, structure, and history of the solid Earth would not have been possible: all modern global standard Earth models and numerous regional models are based on data collected at the ISC and were often initiated by
IASPEI working groups such as the Preliminary Reference Earth Model (PREM) (Dziewonski and Anderson, 1981) and the seismic travel-time models IASPEI91 (Kennett and Engdahl, 1991), SP6 (Morelli and Dziewonski, 1993) and AK135 (Kennett et al., 1995). Since 2008, AK135 has been the standard travel-time table for locating seismic events at the ISC.

The scientific interests of the association were not only focused on seismological topics, but on all questions related to structure and physical properties within the Earth. Consequently, during the Ninth IUGG General Assembly in Brussels (1951), the association changed its name to the current IASPEI and added to its fields of interest tectonophysics, geothermy, radioactivity, petrophysics, geodynamics, elasticity, and plasticity. A new Commission of Physics of the Earth's Interior (Commission de Physique de l'Intérieur de la Terre, today the IASPEI Commission on Earth Structure and Geodynamics) was formed and later IASPEI became involved in many international projects with designated working groups and sessions during general and scientific assemblies such as the international Upper Mantle Project (1964-1970), the Geodynamics Project (1970-1979), and the still ongoing International Lithosphere Program (ILP) (since 1980).

The now $\sim 50$-year-old modern understanding of plate tectonics with its principal plate boundary system of subduction zones, transform faults, and spreading ridges would not have been possible without high-quality earthquake locations, stress distributions along plate boundaries derived from seismicity studies, and detailed understanding of earthquake source mechanisms. All these questions and concepts were discussed extensively during many IASPEI assemblies and 
these topics benefited directly from the international cooperation organized by IASPEI (e.g., in the IASPEI Commission on Tectonophysics and Crustal Structure). The same is true for most of the modern 3D tomographic models of seismic velocities in the Earth's mantle, which are based on globally collected travel-time and waveform observations from many international networks of seismometers. These models provide the foundations for modeling convection of material and thermal evolution within the Earth.

\section{The societal impact of IASPEI-promoted research}

All the above-mentioned research topics have as a common goal a better understanding of structure and dynamics of our planet, in its past, present, and future. The most dramatic evidence that the solid Earth is dynamic and in permanent change is earthquakes, volcanic eruptions, and tsunamis. These ground movements and dynamic processes are of basic scientific interest, but they also can have dramatic consequences for life on Earth. Earthquakes have caused millions of casualties during the last 100 years and IASPEI has a major responsibility to help mitigate the social impact and risk of earthquakes, tsunamis, and volcanoes by contributing its globally collected seismological knowledge.

To understand the seismic hazard of specific regions, seismologists in IASPEI and its regional commissions are working on the compilation of earthquake catalogues, which must be as complete as possible, with highly accurate earthquake locations and magnitude estimates. For such studies the best background material is the instrumentally observed seismic event catalogues, compiled in the name or under the umbrella of IASPEI during the last $\sim 100$ years. Since this is a relatively short time period for understanding long-term hazard, special working groups within IASPEI are working on the extension of earthquake catalogues to the past by studying historical sources and/or geological data. Other input to seismic hazard comes from studies of seismotectonics and the current stress field in the Earth's crust based on accurate earthquake source parameters. In particular the physical processes in seismic sources are studied in the IASPEI Commission on Earthquake Source Mechanics and the IASPEI Commission on Earthquake Generation Process - Physics, Modelling, and Monitoring for Forecast.

In contrast to other natural hazards, earthquakes and tsunamis can cause damage and loss of lives at large distances from the actual source due to wave propagation. Seismic (and tsunami) wave propagation and their effects have always been topics of IASPEI commissions or working groups. It is a long tradition in IASPEI to organize special symposia after large earthquake catastrophes or other important seismic events. In the earthquake hazard arena, close cooperation with the earthquake engineering community is essential, where members of the IASPEI Commission on Earthquake Hazard, Risk, and Strong Ground Motion contribute with physical knowledge about seismic wave propagation in soil and buildings and probabilistic assessments of the frequency of certain levels of shaking exposure to help mitigate seismic risk by informed engineering.

The first nuclear weapon test in the desert of New Mexico on 16 July 1945 was recorded by seismic stations (Gutenberg, 1946), introducing a new role for seismological monitoring. The political need for monitoring global nuclear weapon tests helped the international seismological community to develop new seismic instrumentations, to request funding for basic seismological research and cooperation, and to install new seismic stations and networks. IASPEI has always been very active in collecting information to obtain very accurately located seismic events. This information has been very helpful in testing location algorithms, travel-time models, and in calibrating the International Monitoring System of the Comprehensive Nuclear-Test-Ban Treaty Organization (CTBTO), which has been operational during the last two decades. In this way, IASPEI and its members directly contribute to making the Earth a safer place in which to live.

\section{IASPEI: regional commissions and the International Federation of Digital Seismograph Networks (FDSN)}

In addition to IASPEI's global research activities, it became clear that fostering enhanced regional cooperation and coordination is also needed for both research and hazard applications. As a first step, IASPEI founded in 1951 the Commission pour l'etude des problemes seismologiques Européens (Commission to study European Seismological Problems), which became the nucleus for the well-established European Seismological Commission (ESC). It is worth noting that this commission was for decades one of the few organizations keeping contact and data exchange open between countries in the politically divided Europe after World War II. Later, more regional commissions were founded: in 1996 the Asian Seismological Commission (ASC), in 2011 the African Seismological Commission (AfSC), and in 2013 the Latin American and Caribbean Seismological Commission (LACSC). These regional commissions, with their biannual general assemblies, play today an important role in IASPEI activities.

During its early years, the association played a steady role in testing seismic instruments and promoting the installation of seismic stations. However, during the last few decades many high-quality seismic instruments were developed and today the quality of seismic recordings depends much less on instrumentation and more on local site and installation conditions. In parallel, many new national and international seismic networks have been established and are recording digital seismic signals of high quality, which are often accessible by seismologists in near-real time. To coordinate network planning and to develop standards in digital data quality, exchange, and archiving, the International Federation of Digital 
Seismograph Networks (FDSN) was founded in 1986 during the XX ESC General Assembly (in Kiel, Germany) and acquired the status of an IASPEI commission.

\section{Future of IASPEI}

The future of IASPEI is of course dependent on continuation of international funding and voluntary support of its members, the international seismological community. These factors are closely related to the general social and economic developments in the different member countries and in terms of how much (international) seismological research can contribute to an improved understanding of the dynamic processes in the Earth.

In any case, IASPEI will continue to have a key function in coordinating international cooperation for the seismic monitoring of planet Earth, investigating internal structure, and contributing to the mitigation of earthquake risk. An important aspect of IASPEI activities is that IASPEI assemblies have been organized on different continents and in different countries. This enables different countries and regions to engage with IASPEI and provides opportunities for their researchers to participate in the assemblies and to become acquainted with the global community. The IASPEI regional commissions have a similar function for the different regions. This activity will stay as an important contribution to international scientific cooperation across political and cultural differences.

IASPEI will continue to be the global forum for the definition of all types of standards related to analysis and interpretation of seismic data. After adopting such standards, IASPEI remains committed to its international educational mission to promote and ascertain their application, e.g., by the IASPEI Commission on Education and Outreach.

IASPEI is represented and participates in many IUGG activities (e.g., the Union Commissions Mathematical Geophysics and Study of the Earth's Deep Interior), InterAssociation Commissions (e.g., International Heat Flow Commission, International Ocean Network, Tsunami Commission, Commission on Volcano Seismology), and working groups (e.g., Electromagnetic Studies of Earthquakes and Volcanoes, Seismogeodesy). This results in joint scientific assemblies with other IUGG associations (e.g., in 2003 with IAGA, in 2013 with IAHS and IAPSO, and in 2017 with IAG) and topic-specific symposia during its assemblies. By this effort, IASPEI supports its affiliated members in their interests for exciting, but often very challenging, interdisciplinary research.

Data availability. No other data than those cited in the literature have been used for this contribution.
Author contributions. JS prepared the manuscript with editing and comments from TL.

Competing interests. The authors declare that they have no conflict of interest.

Special issue statement. This article is part of the special issue "The International Union of Geodesy and Geophysics: from different spheres to a common globe" (https://www.hist-geo-space-sci. net/special_issue996.html). It is not associated with a conference.

Acknowledgements. We thank Josep Batlló, Bob Engdahl, Myrto Pirli, Zhongliang $\mathrm{Wu}$, an anonymous reviewer, and the editors for suggestions and corrections to improve this contribution. Josep Batlló also helped to search through old IASPEI publications.

Edited by: Alik Ismail-Zadeh

Reviewed by: Zhongliang Wu and one anonymous referee

\section{References}

Adams, R. D.: International Seismology, chap. 4, in: IASPEI International Handbook of Earthquake and Engineering Seismology, Part A, edited by: Lee, W. H. K., Kanamori, H., Jennings, P. C., and Kisslinger, C., Academic Press, London + San Diego, 29-37, 2002.

Berlage Jr., H. P.: Seismometer, in: Handbuch der Geophysik, 1929-1932, edited by: Gutenberg, B., Verlag Bornträger, Berlin, Band 4, 299-526, 1930.

Bormann, P. (Ed.): New Manual of Seismological Observatory Practice (NMSOP-2), 2nd (revised) edn., Deutsches GeoForschungsZentrum GFZ, Potsdam, https://doi.org/10.2312/GFZ.NMSOP-2, 2012.

Bormann, P., Storchak, D. A., Schweitzer, J.: The IASPEI standard nomenclature of seismic phases, in: New Manual of Seismological Observatory Practice 2 (NMSOP-2), edited by: Bormann, P., Deutsches GeoForschungsZentrum GFZ, Potsdam, 120, https://doi.org/10.2312/GFZ.NMSOP-2_IS_2.1, 2013.

Davison, C.: The founders of seismology, Cambridge, Univ. Press, X, 240 pp., 1927; reprint: Arno Press, New York, 240 pp., 1978.

de Kövesligethy, R.: Comptes-rendus des séances de la cinquième conférence de la Commission permanente et de la troisième et dernière Assemblée générale, Assemblée générale de dissolution de l'Association internationale de sismologie: réunies à Strasbourg les 24 et 25 avril 1922, rédigés par l'ancien Secrétairegénéral R. de Kövesligethy, Hornyanszky, Budapest, 81 pp., 1922.

Dewey, J. and Byerly, P.: The early history of seismometry (to 1900), B. Seismol. Soc. Am., 59, 183-227, 1969.

Dziewonski, A. M. and Anderson, D. L.: Preliminary reference Earth model, Phys. Earth Planet. In., 25, 297-356, 1981.

Ehlert, R.: Zusammenstellung, Erläuterung und kritische Beurtheilung der wichtigsten Seismometer mit besonderer Berücksichtigung ihrer praktischen Verwendbarkeit, Beiträge zur Geophysik, 3, 350-475, 1898. 
Ferrari, G. (Ed.): Gli strumenti sismici storici Italia e contesto europeo - Historical seismic instruments: Italy and the European framework, Istituto Nazionale di Geofisica, Bologna, 1990.

Ferrari, G. (Ed.): Two hundred years of seismic instruments in Italy 1731-1940, Istituto Nazionale di Geofisica, Bologna, 1992

Galitzin, B. B. (Fürst B. Galitzin): Vorlesungen über Seismometrie, deutsche Bearbeitung unter Mitwirkung von C. Reinfeldt, herausgegeben von O. Hecker, Druck und Verlag von B. G. Teubner, Leipzig, Berlin, 1914.

Gutenberg, B.: Interpretation of records obtained from the New Mexico atomic bomb test, July 16, 1945, B. Seismol. Soc. Am., 36, 327-330, 1946.

Hodgson, J. H.: Our Association, its Past as a Guide to its Future. Association Internationale de Séismologie et de Physique de L'Intérieurde la Terre, Comptes Rendus de Séances de la Quatorziéme Conférence Réunie à Zurich du 25 Septembre au 6 Octobre 1967, 15, Première Partie, 12-28, 1967.

Jeffreys, H. and Bullen, K. E.: Seismological Tables, British Association for the Advancement of Science, London, 1940.

Kennett, B. L. N. and Engdahl, E. R.: Travel times for global earthquake location and phase identification, Geophys. J. Int., 105, 429-466, 1991.

Kennett, B. L. N., Engdahl, E. R., and Buland, R.: Constraints on seismic velocities in the Earth from traveltimes, Geophys. J. Int., 122, 108-124, 1995.

Lehmann, I.: P', Publications du Bureau Central Séismologique International, Série A, Travaux Scientifiques, 14, 87-115, 1936.

Morelli, A. and Dziewonski, A. M.: Body-wave traveltimes and a spherically symmetric P- and S-wave velocity model, Geophys. J. Int., 112, 178-194, 1993.

Rothé, J.-P.: Fifty years of history of the International Association of Seismology (1901-1951), B. Seismol. Soc. Am., 71, 905-923, 1981.

Rudolph, E. (Ed.): Verhandlungen der vom 11. bis 13. April 1901 zu Strassburg abgehaltenen ersten internationalen seismologischen Konferenz, redigiert vom Sekretär der Konferenz Prof. Dr. E. Rudolph, Comptes-rendus des séances de la premiére conférence sismologique internationale réunie à Strasbourg du $11 \mathrm{au}$ 13 avril 1901, rédigés par le Secrétaire de la Conférence Prof. Dr. E. Rudolph, Beiträge zur Geophysik, Ergänzungsband I, Verlag Wilhelm Engelmann, Leipzig, 1902.
Rudolph, E. (Ed.): Verhandlungen der vom 24. - 28. Juli 1903 zu Strassburg abgehaltenen zweiten internationalen seismologischen Konferenz, redigiert vom Sekretär der Konferenz Prof. Dr. E. Rudolph, Comptes-rendus des séances de la deuxième conférence sismologique internationale réunie à Strasbourg du 24 au 28 juillet 1903, rédigés par le Secrétaire de la Conférence Prof. Dr. E. Rudolph, Beiträge zur Geophysik, Ergänzungsband II, Verlag Wilhelm Engelmann, Leipzig, 1904.

Schweitzer, J.: Early German contributions to modern seismology, chap. 79.24, Part A, in: IASPEI International Handbook of Earthquake and Engineering Seismology, Part B, edited by: Lee, W. H. K., Kanamori, H., Jennings, P. C., and Kisslinger, C., Academic Press, London + San Diego, Handbook CD \#2, 2003.

Schweitzer, J.: The birth of modern seismology in the nineteenth and twentieth centuries, Earth Sci. Hist., 26, 263-280, 2007.

Schweitzer, J. and Lee, W. H. K.: Old seismic bulletins: a collective heritage from early seismologist, chap. 88, in: IASPEI International Handbook of Earthquake and Engineering Seismology, edited by: Lee, W. H. K., Kanamori, H., Jennings, P. C., and Kisslinger, C., Academic Press, London + San Diego, 81, 16651723, 2003.

Sieberg, A.: Handbuch der Erdbebenkunde, Vieweg Verlag, Braunschweig 1904, XVII + 360 pp., 1904.

Stoneley, R.: The History of the International Seismological Summary, Geophys. J. Roy. Astr. S., 20, 343-349, 1970.

von dem Borne, G.: Seismische Registrierungen in Göttingen, Juli bis Dezember 1903, Nachrichten von der Königlichen Gesellschaft der Wissenschaften zu Göttingen, Mathematischphysikalische Klasse, 440-464, 1904.

von Rebeur-Paschwitz, E.: The earthquake of Tokio, April 18, 1889. Nature, 40, 294-295, 1889.

von Rebeur-Paschwitz, E.: Das Horizontalpendel und seine Anwendung zur Beobachtung der absoluten und relativen RichtungsAenderungen der Lothlinie, Nova Acta der Ksl. Leop-Carol Deutschen Akademie der Naturforscher, LX(1), Halle, 1892.

von Rebeur-Paschwitz, E.: Vorschläge zur Errichtung eines internationalen Systems von Erdbeben-Stationen, Beiträge zur Geophysik, 2, 773-782, 1895. 